\title{
KUALITAS FISIK RUMAH PENDERITA TB PARU DI WILAYAH KERJA PUSKESMAS I KEMBARAN KABUPATEN BANYUMAS TAHUN 2018
}

\author{
Finish Kuntari ${ }^{1}$ ), Budi Utomo ${ }^{2}$ ) \\ Jurusan Kesehatan Lingkungan, Politeknik Kesehatan Kemenkes Semarang, \\ Jl.Raya Baturaden KM 12 Purwokerto, Indonesia
}

\begin{abstract}
Abstrak
[Kualitas fisik rumah penderita tb paru di wilayah kerja Puskesmas I Kembaran Kabupaten Banyumas Tahun 2018]. Tuberculosis (TB) Paru adalah penyakit infeksi menular yang disebabkan oleh Mycobacterium tuberculosis, kuman tersebut masuk kedalam tubuh manusia melalui udara pernafasan ke dalam paru. Berdasarkan data Dinas Kesehtan Kabupaten Banyumas Tahun 2016, untuk wilayah kerja Puskesmas I Kembaran ditemukan kasus baru penderita TB BTA + dengan jumlah 8 orang dan jumlah seluruh kasus TB Paru yaitu 27 orang. Oleh karena itu perlu dilakukan observasi agar mengetahui penyebab timbulnya penyakit TB Paru meliputi luas ventilasi, pencahayaan, kelembaban dan suhu.

Metode penelitian yang digunakan adalah deskriptif observasional yaitu dengan mendeskripsikan variabel-variabel penelitian dengan cara melakukan observasi pada kualitas fisik penderita TB Paru dengan jumlah sampel 28 rumah. Analisis data yang digunakan adalah analisis deskriptif dengan menggunakan distribusi frekuensi dan variabel-variabel penelitian yang disajikan dalam bentuk tabel dengan membandingkan hasil dengan Keputusan Menteri Kesehatan Republik Indonesia Nomor 829/MENKES/SK/VII/1999 tentang Persyaratan Kesehatan Perumahan.Kesimpulanya adalah pada 28 rumah penderita TB Paru di wilayah Kerja Puskesmas I Kembaran dikategorikan sebagai rumah tidak sehat dengan kriteria rumah yang tidak memenuhi standar kesehatan.
\end{abstract}

Kata kunci : Kualitas Fisik, TB Paru, dan Kesimpulan

\begin{abstract}
[The Quality of the physical the person with TB Pulmonologist In Puskesmas I Kembaran Banyumas Regency In 2018]. Tuberculosis (TB) Lung is a contagious infectious disease caused by Mycobacterium tuberculosis, the germ enters the human body by breathing air into the lungs. Based on the data of Banyumas District Health Office of 2016, for the work area of Puskesmas I Kembaran, there are new cases of TB $+T B$ patients with 8 people and the total number of cases of Pulmonary TB is 27 people. Therefore it is necessary to observe to know the cause of the incidence of Pulmonary TB disease covering wide of ventilation, lighting, humidity and temperature.

The research method used is descriptive observasional that is by describing research variables by doing observation on physical quality of patient of Pulmonary TB with sample number 28 house. Data analysis used is descriptive analysis by using frequency distribution and research variables presented in table form by comparing the result with Decree of Minister of Health of Republic Indonesia Number 829 / MENKES / SK / VII / 1999 concerning Housing Health Requirement.The conclusion is that 28 houses of Pulmonary TB patients in the work area of Puskesmas I Kembaran are categorized as unhealthy house with criteria of house that do not meet health standard.
\end{abstract}

Keywords : Physicalquality, TB Lungs, and Conclusion 


\section{Pendahuluan}

Menurut HL.Blum, faktor- faktor yang mempengaruhi kesehatan baik individu, kelompok, dan masyarakat dikelompokkan menjadi 4,yaitu: lingkungan (mencakup lingkungan fisik, sosial, budaya, politik, ekonomi, dan sebagainya), perilaku, pelayanan kesehatan, dan keturunan. Keempat faktor tersebut dalam mempengaruhi kesehatan tidak berdiri sendiri, namun masing-masing saling mempengaruhi satu sama lain. Faktor lingkungan selain langsung mempengaruhi kesehatan juga mempengaruhi perilaku, dan perilaku sebaliknya juga mempengaruhi lingkungan.

Tuberculosis TB Paru adalah suatu penyakit menular yang disebabkan oleh mycrobacterium tuberculosis dan bersifat menular. WHO menyatakan bahwa sepertiga penduduk dunia telah terinfeksi kuman tuberculosis. Setiap detik ada orang terinfeksi (WHO, 2000). Di Indonesia pemberantasan penyakit TB Paru sudah di mulai sejak 1950 dan sesuai rekomendasi WHO sejak tahun 1986 regimen pengobatan yang semula 12 bulan diganti dengan 6-9 bulan. Strategi pengobatan ini disebut DOTS (Directly Observed Treatment Short Course Chemotherapy). Cakupan pengobatan dengan strategi DOTS tahun 2000 dengan perhitungan populasi 26 juta, baru mencapai 28\% (Depkes RI, 1997).

Kondisi rumah dan lingkungan yang tidak memenuhi syarat kesehatan merupakan faktor risiko sumber penularan penyakit TB Paru. Sumber penularan penyakit ini erat kaitanya dengan kondisi sanitasi rumah, faktor risiko dan lingkungan pada bangunan rumah yang dapat mempengaruhi kejadian penyakit maupun kecelakaan antara lain: ventilasi, pencahayaan, kepadatan hunian, kelembaban ruangan, dan binatang penular penyakit (Direktorat Jendral PPM \& PL,2002, Hal 2).

Melihat latar belakang diatas, maka penulis tertarik untuk melakukan penelitian dengan judul " Studi Kualitas Fisik Rumah Penderita TB Paru Di Wilayah Kerja Puskesmas I Kembaran Kabupaten Banyumas Tahun 2018".

Tujuan riset ini adalah mengetahui kualitas fisik rumah penderita TB Paru di Wilayah Kerja Puskesmas I Kembaran Tahun 2018.

\section{Bahan dan Metode}

Subyek yang diteliti adalah penderita TB Paru di wilayah kerja Puskesmas I Kembaran. Obyek penelitiannya adalah rumah penderita TB Paru di wilayah kerja Puskesmas I Kembaran, Kabupaten Banyumas. Jumlah keseluruhan kasus TB Paru di wilayah kerja Puskesmas I Kembaran bulan Januari-Desember 2017 adalah sebanyak 28 kasus dan 3 penderita sudah meninggal dunia sehingga jumlahnya 25 kasus.

Jenis penelitian yang dilakukan yaitu penelitian deskriptif observasional, dengan mendeskripsikan variabel-variabel penelitian dengan cara melakukan observasi pada kualitas fisik rumah penderita TB Paru.

\section{Hasil dan Pembahasan}

\section{a. Gambaran Umum Wilayah Kerja Puskesmas I Kembaran}

Puskesmas I Kembaran merupakan salah satu puskesmas yang berada di Kecamatan Kembaran yang memiliki luas wilayah 25,92 $\mathrm{km}^{2}$. Terbagi dalam 8 Desa/Kelurahan yang berada di Kecamatan Kembaran, antara lain Desa Tambaksari, Bantarwuni, Dukuhwaluh, Karangsoka, Karangsari, Kembaran, Purbadana, dan Linggasari. Desa yang memiliki wilayah paling luas adalah Desa Linggasari yaitu 229,55 ha dan Desa Karangsoka adalah desa tersempit dengan luas wilayah 73,37 ha.

Suhu yang tercatat dari hasil pengumpulan data rata-ratanya adalah $29,89^{\circ} \mathrm{C}$, maka dapat dikatakan bahwa suhu rumah penderita TB Paru di wilayah kerja Puskesmas I Kembaran memenuhi persyaratan kesehatan dengan range $18^{\circ} \mathrm{C}$ $30^{\circ} \mathrm{C}$, sesuai dengan Kepmenkes RI No 829/Menkes/SK/VII/1999 nyaman untuk istirahat bagi manusia.

Karakterisitik untuk jenis kelamin di wilayah kerja Puskesmas I Kembaran paling banyak adalah laki-laki dengan jumlah 19.472 orang atau $50,92 \%$ sedangkan untuk perempuan berjumlah 18.771 orang atau $49,08 \%$. Kepadatan penduduk di wilayah kerja Puskesmas I Kembaran sebesar 3.241 jiwa $/ \mathrm{km}^{2}$, dengan jumlah tertinggi adalah Desa Dukuhwaluh 4.086 jiwa $/ \mathrm{km}^{2}$ dan terendah di Desa Desa Linggasari yaitu 2.655 jiwa/ $/ \mathrm{km}^{2}$.

Kepadatan penduduk yang tinggi dapat memicu terjadinya berbagai macam penyakit yang berbasis lingkungan salah satunya ada lah penyakit TB Paru karena dengan padatnya penduduk akan memudahkan terjadinya penularan, sedangkan tingkat pendidikan paling banyak adalah lulusan SD/MI yaitu sebanyak sebanyak 15.516 jiwa atau $48,81 \%$ dari total penduduk usia 10 tahun ke atas. Rendahnya tingkat pendidikan menyebabkan kurang pengetahuanya masyarakat mengenai pola hidup bersih dan sehat, sehingga masyarakat 
sulit dalam menerima pengetahuan mengenai kesehatan karena masyarakat yang berpendidikan tinggi hanya sedikit.

\section{b. Data Umum}

1) Distrubusi Umur Pada Penderita $\mathrm{TB}$ Paru

Berdasarkan hasil wawancara diperoleh data umur pada penderita TB Paru di wilayah Kerja Puskesmas I Kembaran, kelompok umur yang paling banyak menderita TB Paru adalah kelompok umur 50-59 tahun sebanyak 7 orang (25\%) dan yang paling sedikit adalah kelompok umur 10-19 tahun yaitu 1 orang $(3,57 \%)$ seperti yang tertera pada tabel di bawah ini :

Tabel 1.1 T Jumlah Penderita Penyakit TB Paru Berdasarkan Umur

\begin{tabular}{lccc}
\hline No. & $\begin{array}{c}\text { Umur } \\
\text { (Tahun) }\end{array}$ & Jumlah & $\%$ \\
\hline 1 & $0-9$ & 3 & 10.7 \\
\hline 2 & $10-19$ & 1 & 3.57 \\
\hline 3 & $20-29$ & 5 & 17.8 \\
\hline 4 & $30-39$ & 3 & 10.7 \\
\hline 5. & $40-49$ & 6 & 21.42 \\
\hline 6. & $50-59$ & 7 & 25 \\
\hline 7. & $>60$ & 3 & 10.7 \\
\hline & Jumlah & 28 & 100 \\
\hline
\end{tabular}

Berdasarkan tabel 1.1 Penderita TB Paru di wilayah kerja Puskesmas I Kembaran yang paling banyak berusia antara 50-59 tahun yaitu 7 orang atau $25 \%$, sedangkan umur 40-49 tahun 6 orang atau $21,42 \%$ dari jumlah penderita 28 orang. Hal ini dikarenakan pada usia lansia terjadi kemunduran perkembangan sel, akibatnya kekebalan tubuh akan menurun dan akan mudah terserang bakteri.

2) Distribusi Jenis Kelamin Pada Penderita TB Paru

Berdasarkan data TB Paru yang diperoleh dari Puskesmas I Kembaran, kelompok jenis kelamin yang paling banyak menderita adalah perempuan dengan jumlah 17 orang atau 60,7\% sedangkan untuk laki-laki yaitu sebanyak 11 orang atau $39,28 \%$, seperti tertera pada tabel 2.1
Tabel 2.1 Jumlah Penderita TB Paru Berdasarkan Jenis Kelamin

\begin{tabular}{lccc}
\hline No. & $\begin{array}{c}\text { Jenis } \\
\text { Kelamin }\end{array}$ & Jumlah & $\%$ \\
\hline 1 & Laki-Laki & 11 & 39,28 \\
\hline 2 & Perempuan & 17 & 60,72 \\
\hline 3 & Jumlah & 28 & 100 \\
\hline Berdasarkan tabel & 2.1 & Karakteristik \\
penderita TB Paru di wilayah kerja & Kuskesmas I Kembaran yaitu \\
Perempuan 17 orang atau 60,71\% dan \\
laki-laki 11 orang atau 39,29\% dari \\
jumlah seluruh penderita 28 orang. Data \\
yang diperoleh menunjukan bahwa \\
jumlah perempuan lebih banyak dari \\
pada jumlah laki-laki
\end{tabular}

3) Distribusi Penderita TB Paru Berdasarkan Pekerjaan

Berdasarkan data yang diperoleh dari Puskesmas I Kembaran, karakteristik penderita berdasarkan pekerjaan paling banyak adalah Ibu Rumah Tangga (IRT) dengan jumlah 14 orang atau 50\% dan paling sedikit adalah petani dengan jumlah 1 orang atau $3,57 \%$, seperti tertera pada tabel 3.1

Tabel 3.1 Distribusi Penderita Penyakit TB Paru Berdasarkan Pekerjaan

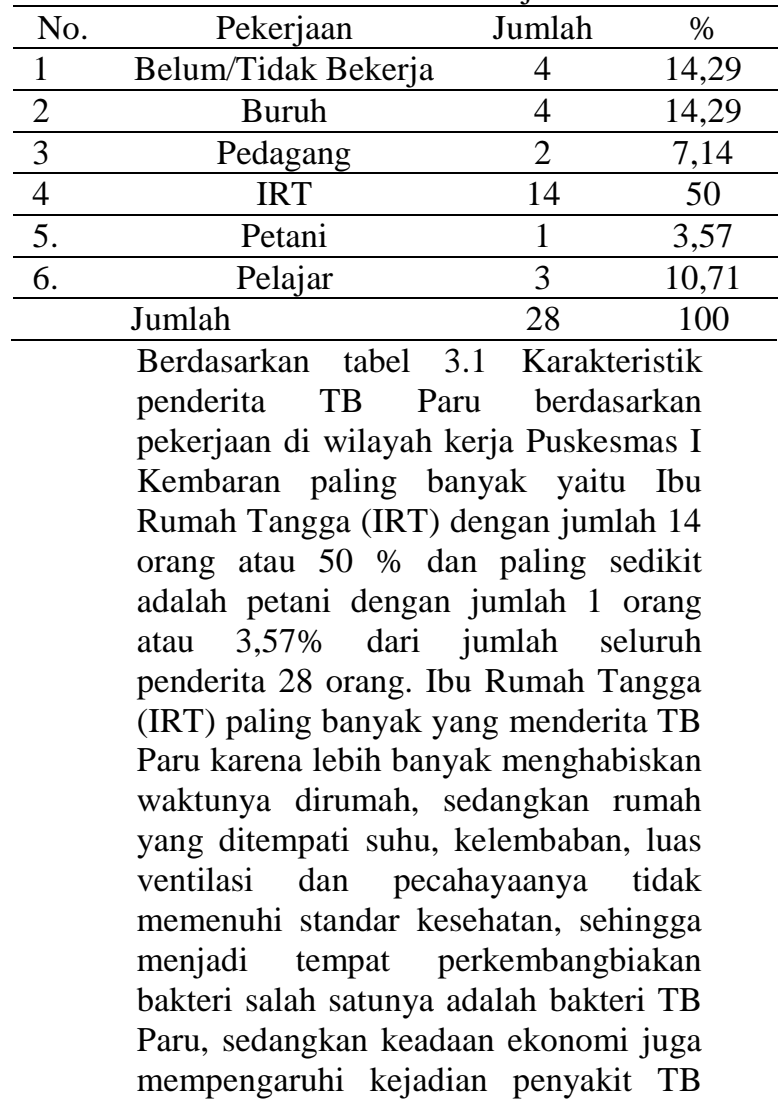


Paru, makin buruk keadaan ekonomi masyarakat maka makin jelek nilai gizi yang didapat, yang akan menyebabkan rendahnya daya tahan tubuh mereka (Koes Irianto, 2015).

4) Distribusi Penderita Penyakit TB Paru Berdasarkan Tempat

Berdasarkan data yang diperoleh dari Puskesmas I Kembaran, Desa Dukuhwaluh dan Desa Purbadana merupakan desa dengan jumlah penderita terbanyak yaitu masingmasing 6 orang $(21,42 \%)$. Sedangkan untuk desa yang penderitanya paling sedikit adalah Desa Kembaran yaitu 1 orang $(3,57 \%)$, seperti tertera pada tabel 4.1 :

Tabel 4.1 Jumlah Penderita Penyakit TB Paru Berdasarkan Tempat

\begin{tabular}{lccc}
\hline No. & Nama Desa & Jumlah & $\%$ \\
\hline 1 & Tambaksari & 2 & 7,14 \\
\hline 2 & Bantarwuni & 4 & 14,28 \\
\hline 3 & Dukuhwaluh & 6 & 21,42 \\
\hline 4 & Karangsoka & 0 & 0 \\
\hline 5 & Karangsari & 5 & 17,85 \\
\hline 6 & Purbadana & 6 & 21,42 \\
\hline 7 & Kembaran & 4 & 14,28 \\
\hline 8 & Linggasari & 1 & 3,57 \\
\hline & Jumlah & 28 & 100 \\
\hline
\end{tabular}

Berdasarkan tabel 4.1 Desa Purbadana dan Desa Dukuhwaluh merupakan desa dengan penderita TB Paru paling banyak yaitu masing-masing 6 penderita atau $42,84 \%$ dari jumlah seluruh penderita 28 orang. Hal ini dikarenakan Desa Purbadana dan Desa Dukuhwaluh kepadatan penduduknya tinggi. Kepadatan penduduk di Desa Dukuhwaluh karena terdapat pusat pendidikan sehingga banyak pendatang dari luar daerah yang menetap sementara di Desa Dukuhwaluh, sedangkan kepadatan di Desa Purbadana karena letaknya yang berada tidak jauh dari Desa Dukuhwaluh, sehingga di Desa Purbadana juga banyak pendatang. Kepadatan penduduk di Desa Dukuhwaluh dan Desa Purbadana memudahkan penularan berbagai macam penyakit, salah satunya penyakit TB Paru yang ditularkan melalui udara.

\section{c. Data Khusus}

1) Luas Ventilasi

Setelah dilakukan pengukuran dengan meteran baja, luas ventilasi pada masing-masing kamar rumah penderita
TB Paru diperoleh hasil seperti tertera pada tabel 5.1 dibawah ini :

Tabel 5.1 Distribusi Luas Ventilasi Kamar Tidur Penderita TB Paru Di Wilayah Kerja Puskesmas I Kembaran

\begin{tabular}{lccc}
\hline No. & Kategori & Jumlah & $\%$ \\
\hline 1 & Memenuhi Syarat & 1 & 3,57 \\
\hline 2 & Tidak Memenuhi Syarat & 27 & 96,43 \\
\hline 3 & Jumlah & 28 & 100 \\
\hline
\end{tabular}

Berdasarkan pengukuran yang dilakukan di 28 kamar penderita TB Paru di wilayah kerja Puskesmas I Kembaran dengan menggunakan meteran baja, luas ventilasi yang memenuhi syarat kesehatan $10 \%$ dari luas lantai adalah 1 rumah dengan persentase $3,57 \%$ dan yang tidak memenuhi syarat $<10 \%$ dari luas lantai adalah 27 rumah dengan persentase $96,43 \%$ sedangkan rata-rata luas ventilasi pada kamar penderita TB Paru adalah $3,52 \%$ dari luas lantai dengan maksimum luas ventilasi $10,68 \%$ dari luas lantai dan minimumnya adalah $0,48 \%$ dari luas lantai.

Data tersebut menunjukan bahwa ratarata ventilasi pada kamar tidur penderita TB Paru tidak memenuhi syarat kesehatan. Ventilasi berfungsi sebagai alat keluar masuknya udara segar dari luar kedalam ruangan sehingga dapat mempertahankan temperatur dan kelembaban ruangan. Ventilasi yang memenuhi syarat kesehatan sangat diperlukan untuk mengurangi kepadatan kuman yang disebabkan oleh pertukaran udara yang tidak lancar yang juga dapat menyebabkan temperatur dan kelembaban tinggi.

Menurut Notoatmodjo (2003), salah satu fungsi ventilasi adalah menjaga aliran udara di dalam ruangan tersebut agar tetap segar. Luas ventilasi rumah yang < 10\% dari luas lantai (tidak memenuhi syarat kesehatan) akan mengakibatkan berkurangnya konsentrasi oksigen dan bertambahnya konsentrasi karbondioksida yang bersifat racun bagi penghuninya. Disamping itu, tidak cukupnya ventilasi akan menyebabkan peningkatan kelembaban ruangan karena terjadi proses penguapan cairan dari kulit dan penguapan. Kelembaban ruangan yang tinggi akan menjadi media yang baik untuk tumbuh dan berkembang biaknya bakteri-bakteri patogen termasuk kuman 
Tuberkulosis (Ikeu Nurhidayat dkk.,2007).

Luas penghawaan atau ventilasi alamiah yang permanen memenuhi persyaratan kesehatan minimal 10\% dari luas lantai (Kepmenkes RI No : 829/Menkes/SK/VII/1999), solusi yang dapat diterapkan adalah dengan membuat ventilasi dengan ukuran luas yang disesuaikan dengan luas lantai agar udara yang masuk tidak terlalu besar dan juga tidak terlalu kecil.

2) Intensitas Cahaya

Setelah dilakukan pengukuran intensitas cahaya di dalam kamar tidur masingmasing penderita TB Paru, diperoleh hasil seperti tertera pada tabel 5.2 :

Tabel 5.2 Distribusi Intensitas Cahaya di Kamar Penderita TB Paru

\begin{tabular}{lccc}
\hline No. & Kategori & Jumlah & $\%$ \\
\hline 1 & Memenuhi Syarat & 0 & 0 \\
\hline 2 & Tidak Memenuhi Syarat & 28 & 100 \\
\hline 3 & Jumlah & 28 & 100 \\
\hline
\end{tabular}

Berdasarkan hasil pengukuran intensitas pencahayaan pada 28 kamar penderita TB Paru di wilayah kerja Puskesmas I Kembaran dengan menggunakan Lux meter pada 28 kamar penderita, didapatkan hasil seluruhnya tidak memenuhi syarat kesehatan. Menurut Kepmenkes RI No. 829/Menkes/SK/II/1999 standar intensitas pencahayaan adalah $\geq 60$ lux, sedangkan seluruh rumah penderita TB Paru hasil pengukuran pencahayaanya $<60$ lux. Rata-rata intensitas pencahayaan kamar penderita TB Paru adalah sebesar 22,15 lux dengan maksimum pencahayaan 53,22 lux dan minimum pencahayaan 4,5 lux. Hal ini disebabkan karena letak kamar yang tidak memungkinkan untuk terkena sinar matahari langsung dan kurangnya kesadaran penderita untuk membuka jendela/tirai meskipun pada siang hari.

Menurut Lubis dan Notoatmodjo (2003), cahaya matahari mempunyai sifat membunuh bakteri, terutama kuman Mycobacterium tuberculosa. Menurut Depkes RI (2002), kuman Tuberculosa hanya dapat mati oleh sinar matahari langsung. Oleh sebab itu, rumah dengan standar pencahayaan yang buruk menyebabkan kuman bakteri dapat tumbuh atau hidup lebih lama. Menurut Atmosukarso dan Soeswati (2000), kuman Tuberkulosis dapat bertahan hidup pada tempat yang sejuk, lembab, dan gelap tanpa sinar matahari sampai bertahun-tahun lamanya, dan mati bila terkena sinar matahari, sabun, dan panas api. Rumah yang sinar mataharinya tidak dapat masuk mempunyai risiko menderita Tuberkulosis 3-7 kali dibandingkan dengan rumah yang sinar mataharinya dapat masuk dengan lancar (Ikeu Nurhidayat dkk., 2007).

Pencahayaan alami diperoleh dari sinar matahari masuk dalam ruangan melalui jendela, genting kaca, celah-celah dan bagian terbuka sangat diperlukan, karena sinar matahari selain berguna untuk penerangan juga dapat mengurangi kelembaban ruangan, mengusir keberadaan nyamuk serta dapat membunuh berbagai macam virus termasuk bakteri penyebab penyakit TB Paru karena sinar matahari mengandung sinar ultraviolet. Oleh sebab itu agar dapat membantu penyembuhan pada penderita penyakit TB Paru sebaiknya penderita TB Paru selalu membuka jendela atau tirai pada pagi hingga siang hari.

3) Kelembaban

Hasil pengukuran kelembaban pada 28 kamar penderita TB Paru tertera pada tabel 5.3 dibawah ini :

Tabel 5.3 Distribusi Intensitas Cahaya di Kamar Penderita TB Paru

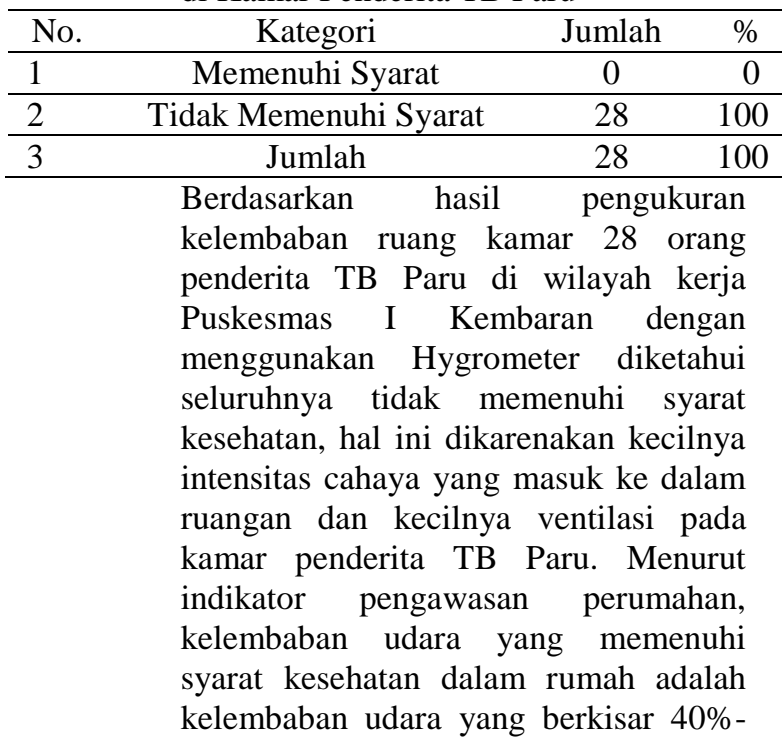


$70 \%$ (Kepmenkes RI No : 829/Menkes/VII/1999)

Kelembaban ruangan yang tidak memenuhi syarat kesehatan dapat menjadi faktor timbulnya penyakit TB Paru, karena salah satu sifat yang dimiliki oleh bakteri Tuberculosis adalah dapat bertahan hidup pada tempat yang memiliki kondisi lingkungan yang lembab. Kelembaban ruangan yang tinggi akan menjadi media yang baik untuk tumbuh dan berkembangbiaknya bakteri-bakteri patogen termasuk kuman Tuberkulosis (Ikeu Nurhidayat dkk., 2007). Kondisi lingkungan yang lembab dapat memperpanjang masa hidup kuman/bakteri di dalam ruangan sehingga dapat memperlambat masa penyembuhan pada penderita. Berbagai cara dapat dilakukan untuk mendapatkan kelembaban rumah yang memenuhi syarat kesehatan $(40 \%$ $70 \%$ ) antara lain dengan pemasangan genting kaca, membuat ventilasi yang cukup serta kebiasaan untuk membuka jendela/tirai pada pagi hari.

4) Suhu

Setelah dilakukan pengukuran suhu masing-masing rumah penderita TB Paru, diperoleh hasil seperti tertera pada tabel 4.15 di bawah ini :

\begin{tabular}{|c|c|}
\hline No. & Kategori \\
\hline 1 & Memenuhi Syarat \\
\hline 2 & $\begin{array}{ccc}\begin{array}{c}\text { Tidak Memenuhi } \\
\text { Syarat }\end{array} & 16 & 57,14 \\
\end{array}$ \\
\hline 3 & Jumlah \\
\hline & $\begin{array}{l}\text { Berdasarkan hasil pengukuran suhu } \\
\text { ruang kamar } 28 \text { orang penderita TB } \\
\text { Paru di wilayah kerja Puskesmas I } \\
\text { Kembaran dengan menggunakan } \\
\text { thermometer diperoleh hasil } 42,86 \% \\
\text { atau } 12 \text { kamar penderita TB Paru } \\
\text { memiliki suhu yang sesuai standar } \\
\text { kesehatan dan } 57,14 \% \text { atau } 16 \text { kamar } \\
\text { penderita TB Paru memiliki suhu yang } \\
\text { tidak sesuai dengan standar kesehatan } \\
\left(>30^{\circ} \mathrm{C} \text { ), sedangkan rata-rata suhu }\right. \\
\text { kamar penderita TB Paru sebesar } \\
29,89^{\circ} \mathrm{C} \text { dengan maksimum suhu } \\
31,86^{\circ} \mathrm{C} \text { dan minimum suhu } 28,6^{\circ} \mathrm{C} \text {. } \\
\text { Berdasarkan Profil Kabupaten } \\
\text { Banyumas suhu di Kabupaten } \\
\text { Banyumas berkisar antara } 21,4^{\circ} \mathrm{C}- \\
30,9^{\circ} \mathrm{C} \text {. udara yang nyaman untuk } \\
\text { Suhu berkisar antara } \\
\text { kesehatan manusia besmenkes Ro No. } \\
18^{\circ} \mathrm{C}-30^{\circ} \mathrm{C} \text { (Kepmenkes }\end{array}$ \\
\hline
\end{tabular}

829/Menkes/SK/VII/1999), sedangkan suhu optimal pertumbuhan bakteri sangat bervariasi, Mycobacterium tuberculosis tumbuh optimal pada suhu $37^{\circ} \mathrm{C}$ (Dwi Purnomo Sidhi, 2010). Menurut Ratih Haribi dan Zoki Abadi Harahap (2009) Mycobacterium tuberculosis adalah kuman obligat aerob atau kuman yang pertumbuhanya membutuhkan oksigen dengan pertumbuhan optimal pada suhu 35$37^{\circ} \mathrm{C}$.

Berdasarkan data yang diperoleh dapat disimpulkan bahwa keadaan suhu ruang kamar tidur penderita rata-rata memenuhi standar kesehatan, sehingga dimungkinkan suhu ruangan ini bukan merupakan faktor yang berkontribusi terhadap kejadian TB Paru di wilayah kerja Puskesmas I Kembaran. Suhu kamar tidur dalam keadaan nyaman sehingga membantu dalam pembentukan daya tahan tubuh serta membantu penyembuhan penderita TB Paru dan memperkecil terjadinya penularan penyakit.

\section{Penutup}

1. Luas ventilasi pada 28 rumah penderita TB Paru yang diperiksa di wilayah kerja Puskesmas I Kembaran memenuhi syarat $10 \%$ dari luas lantai sebanyak 1 rumah atau 3,57\% sedangkan yang tidak memenuhi syarat $<10 \%$ luas lantai sebanyak 27 rumah atau $96,43 \%$

2. Intensitas pencahayaan alami pada ruang tidur 28 rumah penderita TB Paru yang diperiksa di wilayah kerja Puskesmas I Kembaran tidak ada yang memenuhi syarat kesehatan. Syarat intensitas pencahayaan adalah $\geq 60$ lux, sedangakan seluruh ruang tidur penderita TB Paru < 60 lux.

3. Kelembaban ruang tidur pada 28 rumah penderita TB Paru yang diperiksa di wilayah kerja Puskesmas I Kembaran tidak ada yang memenuhi syarat $40-70 \%$ sebanyak 28 rumah atau $100 \%$ kelembaban tidak memenuhi syarat yaitu $<40 \%$ dan $>70 \%$.

4. Suhu ruang tidur pada 28 rumah penderita TB Paru yang diperiksa di wilayah kerja Puskesmas I Kembaran yang memenuhi syarat $18^{\circ} \mathrm{C}-30^{\circ} \mathrm{C}$ sebanyak 12 rumah atau 42,86\% sedangkan yang tidak memenuhi syarat 
$<18^{\circ} \mathrm{C}$ dan $>30^{\circ} \mathrm{C}$ sebanyak 16 rumah atau $57,14 \%$.

\section{Daftar Pustaka}

Aditama,T.Y.2005.Tuberkulosis Diagnosis, Terapi dan Masalahnya.Jakarta: Penerbit Ikatan Dokter Indonesia.

Atmawinata,Edi.2006.Mengenal Beberapa Penyakit Menular Dari Hewan Kepada Manusia.Bandung: Yrama Widya.

Abata,Q.A.2014.Ilmu Penyakit Dalam.Madiun: Yayasan PP AlFurqon.

Bambang Ruswanto (2010).Analisis Spasial Sebaran Kasus Tuberkulosis Paru Ditinjau Dari Faktor Lingkungan Dalam dan Luar Rumah Di Kabupaten Pekalongan, Tesis, Semarang: Progam Pascasarjana Universitas Dipenogoro.

BKPM.2015.Profil Balai Kesehatan Paru Masyarakat Kabupaten Banyumas 2015.Purwokerto: BKPM Kabupaten Banyumas.

Crofton,John.2002.Tuberkulosis Klinis.Jakarta: Penerbit Widya Medika.

Depkes RI.2002.Pedoman Nasional Penanggulangan Tuberkulosis.Jakarta: Depkes RI.

Depkes RI.2002.Pedoman Teknis Penilaian Rumah Sehat.Jakarta: Depkes RI.

Elita Rokhmatun Naeli (2012) Studi Deskriptif Sanitasi Rumah Penderita TB Paru BTA (+) Di Wilayah Kerja Puskesmas II Kembaran Kabupaten Banyumas Tahun 2012, KTI, Purwokerto: Kementerian Kesehatan RI Politeknik Kesehatan Semarang Jurusan Kesehatan Lingkungan Purwokerto.
Gunawan,Rudy.2009.Rencana Rumah Sehat.Yogyakarta: Kanisius.

Irianto, Koes.2015.Memahami Berbagai Penyakit.Bandung:Alfabeta.

Kementerian Kesehatan RI.2016.Profil Kesehatan Indonesia Tahun 2015.Jakarta: Kementerian Kesehatan RI.

Keputusan Menteri Kesehatan RI. Nomor : 829/Menkes/SK/VII/1999.Persyarat an Kesehatan Rumah Tinggal.Jakarta: Kepmenkes RI.

Kunoli, Firdaus.J.2013.Pengantar Epidemiologi Penyakit Menular.Jakarta:Trans Info Media.

May Fadilah (2017) Analisis Faktor Risiko Tuberkulosis Paru Di Wilayah Kerja Puskesmas Kaligondang Kabupaten Purbalingga Tahun 2017, KTI, Purwokerto: Kementerian Kesehatan RI Politeknik Kesehatan Semarang Jurusan Kesehatan Lingkungan Purwokerto

Muttaqin, A.2008.Buku Ajar Asuhan Keperawatan dengan Gangguan Sistem Pernafasan.Jakarta:Salemba Medika.

Soedarto.2009.Penyakit Menular di Indonesia.Jakarta: Sagung Seto.

Tri Cahyono.2018.Panduan Penulisan Tugas Akhir.Purwokerto: Politeknik Kesehatan Semarang Jurusan Kesehatan Lingkungan

Yufa Zuriya (2016).Hubungan Antara Faktor Host Dan Lingkungan Dengan Kejadian TB Paru Di Wilayah Kerja Puskesmas Pamulang, Skripsi, Jakarta : Progam Studi Kesehatan Masyarakat Fakultas Kedokteran Dan Ilmu Kesehatan Universitas Islam Negeri Syarif Hidayatulloh. 